\title{
"Critical assessment of Just-in-Time (JIT) process within a South African company: the case of Sabertek"
}

$\begin{array}{ll}\text { AUTHORS } & \text { Gert Van Wyk } \\ & \text { Vinessa Naidoo id https://orcid.org/0000-0002-2358-5588 } \\ & \text { Gert Van Wyk and Vinessa Naidoo (2016). Critical assessment of Just-in-Time } \\ \text { (JIT) process within a South African company: the case of Sabertek. Investment } \\ \text { MantiCLE INFO } \\ \text { doi:10.21511/imfi.13(3-1).2016.10 }\end{array}$

doi:10.21511/imfi.13(3-1).2016.10

DOI

http://dx.doi.org/10.21511/imfi.13(3-1).2016.10

RELEASED ON

Friday, 23 September 2016

JOURNAL

"Investment Management and Financial Innovations"

FOUNDER

LLC "Consulting Publishing Company "Business Perspectives"

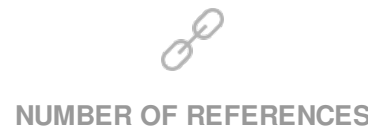

0
NUMBER OF FIGURES

0

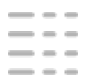

NUMBER OF TABLES

0

(C) The author(s) 2023. This publication is an open access article. 
Gert Van Wyk (South Africa), Vinessa Naidoo (South Africa)

\title{
Critical assessment of Just-in-Time (JIT) process within a South African company: the case of Sabertek
}

\begin{abstract}
The intense competition in the current marketplace has forced local companies to re-examine their methods of doing business to improve product quality and reduce cost of production at a faster ratethan its competitors (Singh \& Ahuja, 2012). The South African manufacturers have struggled with growing trade deficits and outsourced operations. Although proponents cite the many benefits of JIT adoption, its implementation rate in South Africa has been relatively conservative and is highly criticized, especially in comparison with India (Jacobs, 1997; Singh Ahuja, 2014). The purpose of the study is to verify the financial impacts on a company's performance on reduction of waste by implementing the JIT principle. The focus of the study will be looking at the profit derived of a company's production line by comparing the amount of waste reduction of a JIT line, as opposed to a non-JIT line. This is of significant importance, since the profits of a company effects the GDP of South Africa, and increases employment (Jacobs, 1997). This study is a replication from Cua (2000) and is a quantitative study. The case study company, Sabertek, has two different manufacturing plants where one plant uses JIT, whilst the other plant does not use JIT. Structured questionnaires were considered and administered to the senior staff and various technical staff of each plant for the collection of primary data. This was approximately 120 personnel (60 questionnaires in each plant) with a total expected response rate of $30 \%$. This was used to compare the profit of a JIT line, as opposed to a non-JIT line, especially in relation to reduction of waste. Secondary data from the company's financial records of each plant relating to the return rate from rework, sales, profit from the different production lines were equally looked at.
\end{abstract}

Keywords: JIT, market place, profit, JIT line, non-JIT line, primary data, secondary data.

JEL Classification: L10, D21, C8.

\section{Introduction}

Just-in-Time (JIT) is a Japanese-developed manufacturing philosophy that represents "an aesthetic ideal, a natural state of simplicity" with the right quality and quantity in production efficiency (Kootanaee, Babu \& Talari, 2013). Although precisely defining JIT continues to be perplexing, JIT production is generally referred to as a manufacturing system for achieving excellence through continuous quality improvements (Sugimori, Kusunoki, Cho \& Uchikawa, 1977). With regards to productivity, rework of manufactured products and waste has a direct impact on the profits of a company (Schonberger, 1982).

Multiple measures continue to be widely used to measure manufacturing performance. The administrative costs of a manufacturer are generally high with waste generated by production, and can be destructive to the growth of the company. Waste generated is typically related to smaller time frames to satisfy customers and higher inventory levels that are linked to extra interest rates and lower cash flow rework of products that is returned, unproductive travelling and underutilization of the workforce. According to Schmenner and Swink (1998), companies were losing profits because of waste generated with production. It is clear from JIT's efficiencies which is evident from quicker set-up times (time to set a manufacturing

(C) Gert Van Wyk, Vinessa Naidoo, 2016.

Gert Van Wyk, Tshwane University of Technology, Pretoria, South Africa.

Vinessa Naidoo, Dr., Tshwane University of Technology, Pretoria, South Africa. machine), using smaller batch sizes, reducing cycle times and allowing the production system to respond to demand with flexibility and speed (Hayes \& Wheelright, 1984, p. 54).

\section{Review of literature and theoretical background}

Just-in-Time (JIT) is a Japanese-developed manufacturing philosophy that represents "an aesthetic ideal, a natural state of simplicity" with the right quality and quantity in production efficiency (Kootanaee, Babu, \& Talari, 2013). Although precisely defining JIT continues to be perplexing, JIT production is generally referred to as a manufacturing system for achieving excellence through continuous quality improvements (Sugimori, Kusunoki, Cho \& Uchikawa, 1977). With regards to productivity, rework of manufactured products and waste has a direct impact on the profits of a company (Schonberger, 1982). According to Tamura and $\mathrm{Ej}$ (2011), business growth is aligned to profitability. This review aims to provide a better understanding of why companies consider JIT adoption to be financially beneficial and the relevant factors impacted to deliver more than this statement. Improvements resulting from reduced inventory levels are documented in several JIT studies. However, limited observed evidence exists on the business growth (Nahadarajan, 2013). Some survey studies examining the relationship between JIT practices and firm performance, as measured by productivity, leadtime, and quality, has failed to find a significant relationship (Mentzerb, 2008).

However, according to Fullerton and McWatters (2001, pp. 81-96), an improvement in several 
production performance measures subsequent to JIT adoption was reported. In a comparison study of JIT and non-JIT, in the US, JIT has been both praised and criticized for its effectiveness, accounting, in part, for its relatively conservative adoption rate, and due to the desire to meet shareholders expectation on profit, finding a supplier that offer low price is an objective, as well as more effective way of producing products. There are differences between the production processes for conventional and for progressive organizations (Kootanaee, Babu, Talari, 2013).

However, customers demand product with high quality and to be delivered on time. Poor quality delivery or failure to ensure on time delivery can mean huge losses of customer goodwill and commitment (Krajewski, 2008). The Toyota Production System was called the JIT system, as it focused on the total elimination of waste and met the needs of a constantly changing market by providing goods and services when they are needed and in amount needed. Such approach promotes production to order rather than production to inventory. Therefore, inventory control is a key component of the JIT philosophy. In a related development, the JIT concept is driven by the lean way of doing things in terms of waste reduction (McWatters \& Fullerton, 2013). Pump in more orders quantity for JIT parts to vendor without checking the capacity allocation seems having a tight schedule and it might disrupt the delivery smoothly to buyer.

\section{Benefits in using JIT}

Success in using JIT needs the stability of demands and supply. Since long term relations with suppliers are important for stability of supply and its quality, a relation with the customer have an equal importance (Aksoi \& Asli, 2011). Government policies have considerable effects on demand stability, while presence of several independent dealers in one country instead of presence of one or two limited customers in market will provide a better environment for invention (Chase \& Aquilano, 1992). The more customers demand, the more companies will have to empower their competitive superiority, because these customers make the companies to meet much more standards in products quality improvement, pricing and capacity (Ashish, 2006). A lot of the practices associated with JIT also address the issues of variability reduction and smoother workflow and are, therefore, consistent with this theory as well. A Theory of Internal Variability of Production Systems is proposed by Wacker (1987) to understand the complementary nature of manufacturing goals by their relationship to throughput time. $\mathrm{He}$ argues that the major manufacturing goals of demand responsiveness, production efficiency, and high quality are all closely related to internal throughput time and profit. Using mathematical analysis, Wacker (1998) shows that effective preventive maintenance programs improve quality that, in turn, can lead to improvement in internal throughput time. On-time delivery and unit cost improve as throughput time is shortened.

Thus, improvement in quality and throughput time derived from the JIT process lead to better goal and overall company performance. Furthermore, it is shown that internal variability of throughput time is caused by variability in move times and processing times. On the basis of the literature, Wacker (1987) suggests that move times can be shortened by requiring short move distance, high-speed automated moving, and more frequent move policies, all of which are associated with a Just-in-Time production system. Eisenhardt (1989) states that, on the other hand, processing time variability can be reduced by lower rework time and lower down time, both of which can be achieved through systematic preventive maintenance programs.

\section{Problems associated with JIT}

However, fit is more commonly known in terms of contingency theory, a term coined by Lawrence and Lorsch (1967). Contingency theory asserts that the effect of a factor cannot be universally superior in all contexts, but rather depends on its match with the context. Traditionally there are two perspectives in organizational innovation research the logical perspective and the administrative perspective (O’Brian et al., 2009). More recently, researchers are beginning to realize that consistency among different innovations such as technological and administrative innovations is needed to improve an organization's performance with regards to the organization's financial performance (Cohen and Zysman, 1988; Gerwin, 1988; Georgantzas and Shapiro, 1993). Ettlie (1988) labels this phenomenon of simultaneous adoption of compatible technological and administrative innovations as synchronous innovation.

However, even though plants have incorporated JIT practices successfully, manufacturing resources such as plant capacity can certainly affect plant performance (Aksoi \& Asli, 2011). Lack of capacity may result in a plant's inability to meet orders on time and can limit the plant's flexibility in production scheduling and will have a negative affect on the financial performance (Porter, 1980). A high level of plant capacity utilization may reduce per unit fixed costs, but when high capacity is sustained through overtime, variable cost may increase (Krajewski and Ritzman, 1996). Working effectively in teams is also important for problem solving in a JIT environment (Banker et al., 1993b). Im and Lee (1989) declared teamwork essential for JIT implementation. The general consensus is that teamwork cultivation practices should be aligned in a JIT environment (Banker et al., 1993a; Bhimani and Bromwich, 1991; Durden et al., 1999; McNair et al., 1990; Sakakibara et al., 1997; 
Schonberger, 1986; Swenson and Cassidy, 1993). However, studies examining the actual changes in teams with the adoption of JIT report mixed results (Fullerton, 1998; Patell, 1987; Sillince and Sykes, 1995). Managers will be reluctant to implement JIT, if they are not convinced that JIT will enhance overall firm performance. Therefore, a firm's investment in JIT improvements resulting from improved production levels and making quality everybody's job (Lieberman, 1990).

Another critical factor believed to have caused problems in the implementation of JIT is the lack of a support system to facilitate learning and transform learning into effective diffusion of the practices of JIT (Cole, 1998). While JIT encompasses a variety of tools and techniques the use of these tools should be supported by an empowered workforce that can use the data gathered to identify and solve problems (Becker, 1993). The practices of JIT help to eliminate waste arising from an unorganized work area, unplanned downtime, and machine performance variability (Crawford, Blackstone \& Cox, 1988). The goal of JIT is to continually maintain, improve and maximize the condition and effectiveness of equipment through complete involvement of every employee, from top management to shop floor workers (Chase \& Aquilano, 1992). The basic practices of JIT are often called the pillars or elements of JIT.

\section{Research design and methodology}

This study has relied on quantitative research approach, where 120 questionnaires (60 questionnaires in each plant) were distributed. A modified questionnaire from Cua (2000) was used to collect the primary data. The relevant staffs include all senior staff and various technical staff, with an expected total response rate of $30 \%$. Secondary data from the company's financial records of each plant relating to the return rate from rework, sales, profit from the different production lines will also be looked at. The data collected were analyzed using an unpaired t-test technique. The study use Statistics data analysis software (STATA) to analyze the data.

\section{Findings}

The researcher collected all the data related to the Just-in-Time (JIT), and non-JIT manufacturing lines in Sabertek. The data were collected from various employees from different departments, since they had exposure to both manufacturing disciplines. The data were grouped in the respective groups to test the hypothesis. The hypothesis, in this case, is to determine the waste generated and profit generated from a JIT and non-JIT manufacturing line. It also takes into consideration one of the key elements in the implementation of JIT which is employee reaction and teamwork. Organization theory suggests that people will be more compelled to work toward goals when they are included in the development of the goals (Kootanaee, Babu, Talari, 2013). Onto this hypothesis JIT builds the idea of involving employees at different levels in the organization. The introduction of quality circles and the concept of total people involvement are examples of the avenues available for attempting to maximize people involvement through the use of JIT.

According to the statistical findings tabulated by using Pearson's Chi Square to determine the relationships between the Waste and Profit of the respective production lines, the following was found with regards to Inventory holding reduction.

\section{Inventory (WIP) saving at SABERTEK}

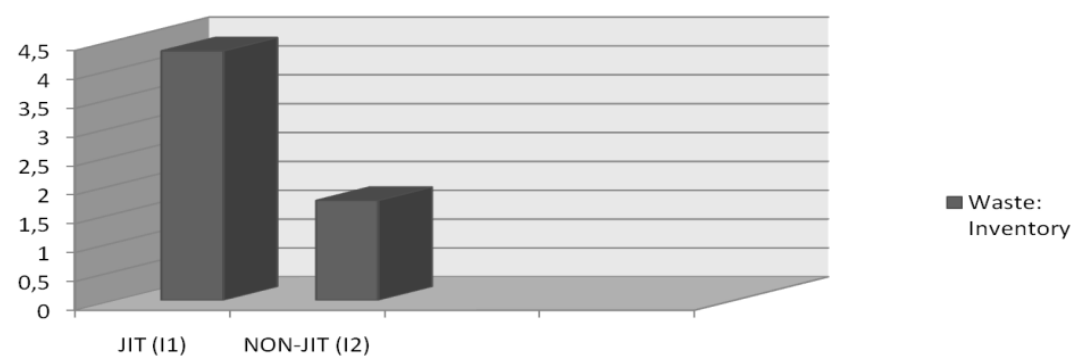

Fig. 1. Manufacturing inventory reduction

From the above depicted Figure 1, the respective means for the different manufacturing lines were 4.37 for a JIT and 1.73 for a non-JIT manufacturing line. Inventory is, probably, one of the factors with the largest impact. It is, however, a factor that needs to be carefully balanced, since it can influence the reaction and flexibility to customer needs. In contrast to traditional manufacturing in Sabertek, JIT manufacturing required production of small lot sizes. Production of small lot sizes was possible by drastically reducing set-up times. According to Cua (2000), small lot sizes in JIT manufacturing is closely associated with improved quality, reduced inventory, reduced manufacturing cost, faster delivery and better market responsiveness. With continuous flow of small lot sizes of information, downstream team members in Sabertek could begin working on different phases of the design, while final design was evolving. A continuous flow of information among team members in Sabertek 
reduced uncertainty and encouraged early detection of problems, which enabled Sabertek to avoid costly, time-consuming changes. Production without defective products needs deletion of those activities which have no added-value on the final product at Sabertek. The most important reason to keep inventory in South Africa is high inflation rate which is considered as a significant problem in JIT system application (Mentzerb, 2008).

Using JIT requires the risk of inflation excitement, like those times when suppliers try to increase the prices due to lack of primary materials (Manoj, 2011). Another reason of preserving the inventories is to avoid a delay in production which can be due to both production lines and supply chain. Successful application of this method relies on coordination of production timetabling with suppliers' inventory, so whenever suppliers' services are in upper level, issues

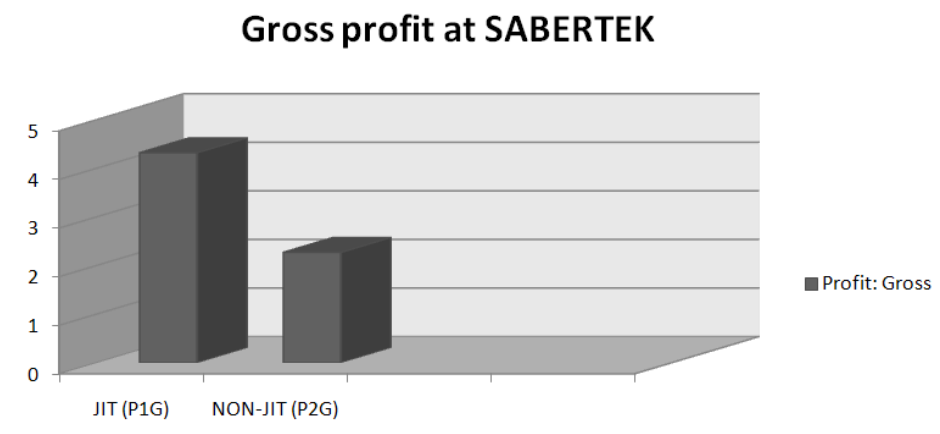

Fig. 2. Gross profit comparison

After collecting the data from respondents a JIT line showed a 3.37 mean with regards to gross profit compared to a 1.28 from a non-JIT line. This increase in profit is in congruence with the literature. It shows a significant difference in profit which was emphasized by the management of Sabertek. This allowed Sabertek to use short-term earnings to be ploughed back into the company to finance the various other changes and investment commitments necessary for JIT success. It should be made clear that most of the benefits associated with of product quality and reliability of inventory would get importance (Mentzerb, 2008). Physical stock means the actual inventory level meanwhile logical stock means stocks level recorded in the bin card or in the computer system. In order to check and balance the logical and physical stocks the move undertaken to conduct stock counts periodically (Chandren, Nadarajan \& Nadarajah, 2012). According to Ashish (2006), the JIT philosophy has been easily applicable and dominant in various industries; it presents a framework for modelling performance of JIT in supply chain on the basis of interdependent variables, by means of analytical network approach.

\section{Profit comparison}

According to the statistical findings tabulated by using Pearson's Chi Square to determine the relationships between the Waste and Profit of the respective production lines, the following was found with regards to Gross Profit.

JIT will only be realized over the long run (Kootanaee, Babu, Talari, 2013). In the Sabertek case, all the waste factors contributed to the increase in Gross Profit. Specifically manufacturing floor space, inventory levels and travelling. The other factors were more visible in the Netto profit of the company. According to the statistical findings tabulated by using Pearson's Chi Square to determine the relationships between the Waste and Profit of the respective production lines, the following was found with regards to Netto Profit.

\section{Netto profit at SABERTEK}

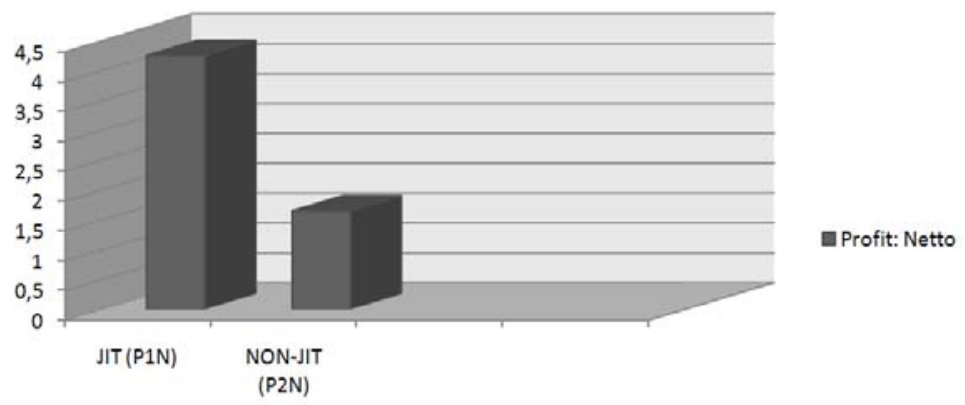

Fig. 3. Netto profit comparison 
In the depicted Figure 3 above, the JIT mean was calculated at 4.25 and the non-JIT at 1.65 . The picture clearly shows that there is an increase in Netto profit to Sabertek. However, the net profit is definitely not what it is supposed to be in a fully operational JIT environment. One must take cognizance of the fact that teams have been broken up and new teams are formed due to the nature of the processes. Although teamwork and the dynamics thereof has increase in the results of the research, teams go through stages being: Forming, Storming, Performing and Adjourning (Kootanaee, Babu, Talari, 2013). This indicates that the teams are still in the Forming stage and not Performing stage. In a more general study on the impact of unionization on firm performance, the author concludes that union influences profit distribution, but has little impact on factors and output of production (Clark, 1994). The discussion suggests that there is no definite argument on the nature of the effect of contextual factors on manufacturing performance (Bollen and Long, 1993). However, we have to acknowledge the possible contribution of contextual factors on performance variations. It is also possible that the effects of contextual factors are manifested through the existence or non-existence and level of implementation of manufacturing practices (MacDuffie and Krafcik, 1992). Thus, we expect that while contextual factors have an impact on manufacturing performance and profit, the level of implementation of manufacturing practices will explain a larger portion of the variability in performance. Furthermore, Sabertek's strategy tend to focus on enhancing the long-run competitiveness rather than emphasizing the realization of short-term profits. They are willing to experience opportunity costs by introducing and implementing innovative ideas within this company. Sabertek is a wellestablished company and is encouraged to maximize long term benefits. This enables them to experience the rewarding long-term profits as a result of their efforts. This case study presented them exactly that opportunity.

This finding is in congruence with the literature where the limitations of JIT are emphasized by Kootanaee, Babu, Talari (2013). Loss of individual autonomy has been suggested as another possible short-coming of JIT. Loss of autonomy has largely been attributed to limited cycle times or the 'time between recurring activities'. Buffers such as slack or idle time are significantly reduced resulting in greater amounts of stress and pressure placed upon the worker to perform. The time which would, otherwise, be present would allow the worker more freedom to perform 'vertical tasks' which constitute administrative tasks or team meeting. In addition, reduced cycle times force workers to adjust immediately to changes in demand without taking their needs into consideration. Loss of team autonomy is a possible result of reducing.

Apart from the fact that the diffusion in South Africa could be a contributing factor in the present study, the association between success factors of JIT implementation and manufacturing performance measures have also been assessed to evolve the recognition of the contributions of the various JIT implementation success factors towards achievement of specific manufacturing performance improvements. According to Kootanaee, Babu, Talari (2013), the outcome of enhancements in manufacturing performance with respect to "time frame of JIT implementation" has been accessed to confirm the fact that JIT implementation is not an overnight process, and it requires quite a reasonable period that varies between three and five years to realise the true profit potential of JIT. According to the statistical findings tabulated by using Pearson's Chi Square to determine the relationships between the JIT and non-JIT production lines, the following was found with regards to Job Creation at Sabertek.

\section{Jobs created at SABERTEK}

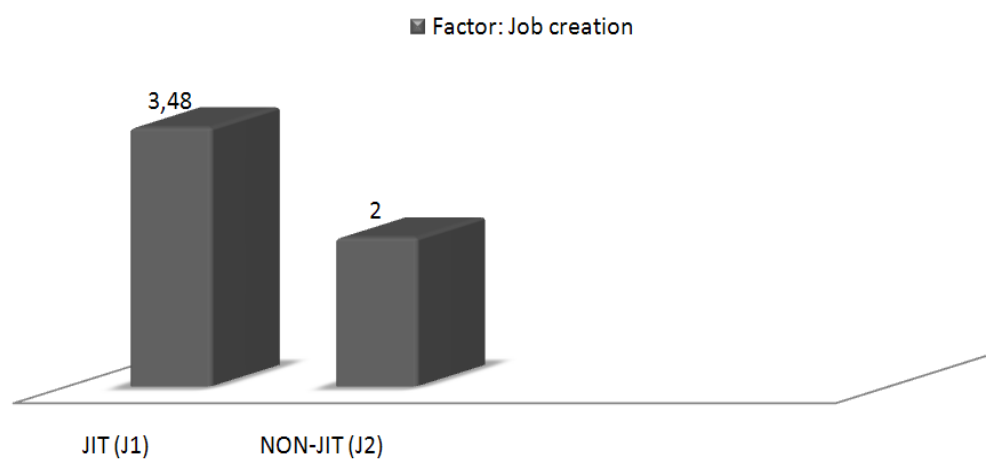

Fig. 4. Job creation comparison

The very soul of JIT implementation is to maximize resources to increase production and ultimately profit with the same amount of costs. The researcher found that there was a fear of job loss when the implementation was announced. This is a normal reaction, and some employees resigned. However, 
once the employees experienced the positive training and multi skilling empowerment result of JIT, all the uncertainties disappeared at Sabertek.

The mean of the JIT environment is 3.48 and 2 at the non-JIT, respectively, where the JIT manufacturing line was clearly creating more jobs than the non-JIT manufacturing line. Job rotation under JIT systems create conditions for job enrichment and job enlargement and at the same time catering for employees' social needs. In JIT environment, problem solving abilities, ability to face challenges and involvement of workers, thereby leading to enhanced equipment maintainability. This is an example of good management changing the natural tendency of people to follow ancient traditions. Furthermore, Imai (1998) believes that JIT waste reduction is a pillar supporting the JIT production system. Huang (1991) discusses the importance of considering the integration of JIT, total quality control, and factory automation with worker and management participation. Thus, the development and implementation relationships of JIT provide support for the simultaneous investigation of their practices and impact on manufacturing performance and ultimately on job creation due to higher capacity (Vickery, 1991).

However, it is clear that there are similarities in the job creation practices and implementation scenarios of JIT. Therefore, this study aims to develop a theory that can explain what provides for a successful joint implementation of JIT and job creation (Bozarth and Edwards, 1997). While the field of Operations Management may be inadequate in theory development (Swamidass and Newell, 1987; Anderson et al., 1989; Flynn et al., 1990; Ahire, Landeros and Golhar, 1995; Swink and Way, 1995) there are building blocks of theory in the existing literature that underlines the connection of JIT implementation and job creation (Schmenner and Swink, 1998). According to the statistical findings tabulated by by using the mean to determine the relationships between the JIT and non-JIT production lines, the following was found with regards to training and empowerment at Sabertek.

\section{Training at SABERTEK}

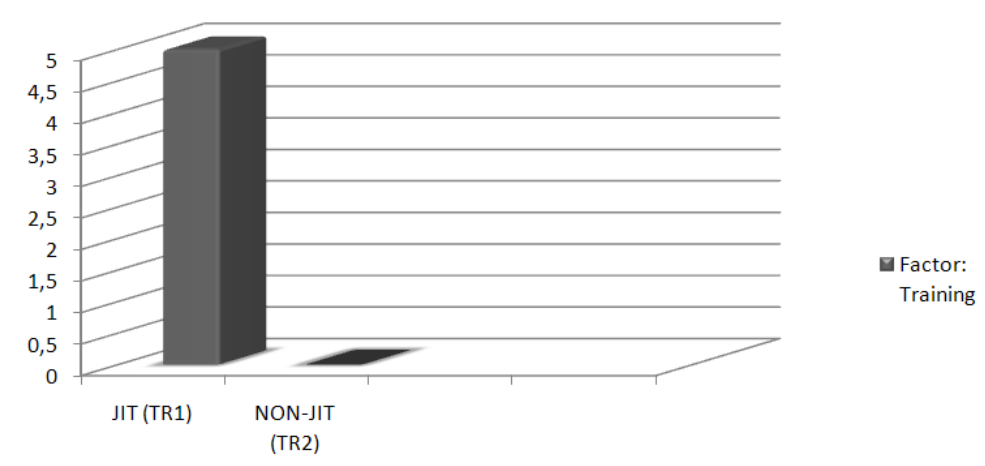

Fig. 5. Training comparison

From the questionnaire, all the employees agreed that training improved in a JIT environment, and none was a non-JIT manufacturing line. JIT education was carried out by visiting implemented sites, using a JIT consultant, conducting classes and seminars, watching video tapes, as well as having on-jobtraining. Sabertek also conducted preliminary studies to help to smooth the implementation process. Apart from the JIT training, other skills related to the manufacturing were done on a regular basis. This created multi skilled employees and Sabertek could minimize its risk of losing a rare skill and made everybody replaceable. The training that was done was official and unofficial. This means that people got proof and certification of training in calibrating a test jig, for instance. It created pride amongst the employees and a hunger for more empowerment. Obviously, when people perform better, they become more valuable to Sabertek since they produce more, and subsequently, get better paid on a regular basis. JIT generated new ideas and ultimately new products for Sabertek. More workshops and seminars promoting and disseminating the JIT concepts, especially to the top management of Sabertek who have not used JIT, were encouraged. In addition, education and training were also required to encourage employee participation and involvement (Pisuchpen, 2012). For manufacturers to adapt to the situation, flexibility is of paramount importance. Though the task of converting the production system to one that uses JIT cannot be accomplished overnight, the existence of hindrances are by no means sufficient to prevent most or many of the companies here from applying JIT (Inman and Mehra, 1990). JIT related literature covering various aspects of its development from the work of the pioneers, academic and practitioner oriented studies and/or surveys of industry practices (Davy, White, 
Merritt \& Gritzmacher, 1992; Mehra \& Inman, 1992; Sakakibara, Flynn, Schroeder \& Morris, 1997; McLachlin, 1997; Sakakibara et al., 1997; Ahmad, 1998). The study of Mehra and Inman (1992) considers four key factors of JIT implementation, namely JIT production strategy, JIT vendor strategy, JIT education strategy and management commitment (Vickery, Dirtige \& Markland, 1993).

\section{Management involvelment at SABERTEK}

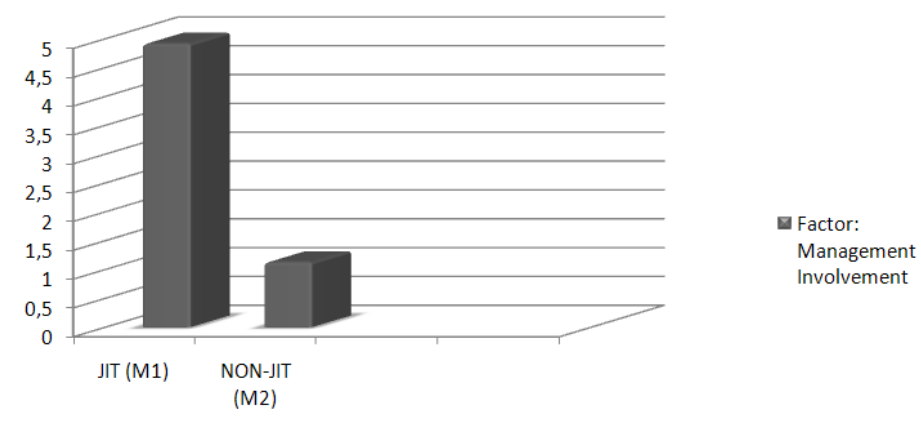

Fig. 6. Management involvement comparison

From the depicted Figure 6, the means of the JIT compared to the non-JIT is 4.91 and 1.13 , respectively. The comparison shows that management involvement in a JIT environment is much higher than a non-JIT manufacturing process. The involvement of management at Sabertek was one of the success factors and why the transformation has been a success. The management made sure that the infrastructure was established to make the implementation possible and the required transition could take place. Further, the management gave clear direction as to where the company was going and what the objectives were. This countered the fear and uncertainty of change in any company and human behavior. The management involvement made information flow to executives easier and problem could be seen earlier and communicated earlier in the process. This in itself illuminated problem in an early stage, and reduced rework dramatically. Some of the implementation factors considered by McKone, Schroeder and Maier (1998) are more related to the development of an environment or mechanism for employees to better implement the JIT techniques of autonomous and planned maintenance. An examination of the practices discussed in the three articles reviewed above reflects the importance given to training and employee involvement. Employee and management involvement is also emphasized as a component of JIT philosophy in the works of Nakajima (1988) and Suzuki (1992). Some authors also consider the steps in a JIT development program (Nakajima, 1988).

Lack of management involvement shows that is the most serious factor with $94 \%$ of JIT and $61 \%$ ofthe non-JIT respondents agreeing on this problem. The successful implementation of a JITPS requires amongst others, redesigning the factory layout and educating the employees on the concept of valueadding activities. As such topmanagement must not only initiate the process of change (Pisuchpen,
2012), but also be fully committed to such changes. The lack of commitment and experience by management may be attributed to relative newness to South Africa, and the time of the total transformation need to be taken into consideration (Jacobs, 1999).

\section{Conclusions and recommendations}

Considering the major improvements observed in Sabertek manufacturing firm after implementation, it seems as if JIT might be practical and advantageous when implemented in small South African manufacturing firms. The need remains, after the case study for the application of international techniques to determine whether JIT is advantageous in small South African production systems that are not subject to batch prepared materials and continuous runs. The impact of JIT in South African firms, as well as the implementation and operating problems, needs to be determined. It is confirmed that JIT improves the productivity of a firm and ultimately of South Africa. It must be emphasized that the questionnaire on which this survey is based only seeked objective facts, as well as accurate and precise statistics that were be quantified. The results are, therefore, of interest to Sabertek who wish to compare its own status with that of the small South African industry as a whole.

The size of a manufacturing firm is used merely for selection to the survey, and not in order to determine a weight that depends on the size of the firm. The opinions of all the manufacturing employees taking part in the survey, irrespective what size, are, thus, treated in the same manner. The answers obtained from the employees varied from the Chief Executive Officer to technical managers. Their responsibilities varied from reporting to the board, to deliveries of the final products. This proved that the questionnaire was structured to capture all relevant factors of the study in Sabertek. 
JIT is conventionally and intellectually defined as a system for manufacturing and supplying only the goods that are needed, only when they are needed, and in the exact quantities needed, instantaneously, with perfect quality and no waste. It is clear from the findings obtained that the Chief Executive Officer (CEO), is the main decision maker and driver of the improvement of revenue for the company. The CEO reports to the board of directors and shareholders. The CEO has various tasks, but the main focus is the creation of value to his shareholders. The involvement of the management was a critical success factor for the implementation. While this conventional definition is true and legitimate, it only defines JIT intellectually. JIT is people centred. The people in the workplace where JIT originates define JIT practically: for them, JIT means trimming losses (Jacobs, 1997).

\section{References}

1. Ahmad, S. (1998). The relationship between JIT managerial practice and JIT infrastructure: Implications for plant performance. PhD. Minneapolis, University of Minnesota.

2. Aksoi, L. \& Asli, M. (2011). Expert Systems with Applications, A journal of efficient logistical system integration, May, 38(5), pp. 6351-6359.

3. Alippi, C. \& Roveri, M. (2008). Just-in-Time adaptive classifiers, Designing the classifier, 19(2), pp. 2053-2064.

4. Anderson, J.C., Cleveland, G. and Schroeder, R.G. (1989). Operations strategy, Journal of Operations Management, 8(2), pp. 133-158.

5. Ashish, A. (2006). Modelling the Metrics of Lean, Agile, Supply Chain: An ANP base Approach, European Journal of Operational Research, 173 (1), Jul., pp. 211-225.

6. Azar, A., Kahnali, R., Ahmadi, T. \& Taghavi, A. (2010). Relationship between Supply Chain Quality Management Practices and their Effects on Organisational Performance, Singapore Management Review, 32(1), Oct., pp. 45-68.

7. Becker, S.W. (1993). TQM does work: Ten reasons why misguided efforts fail, Management Review, 82(5), pp. 30-34.

8. Bollen, K.A. \& Lennox, R.D. (1991). Conventional Wisdom on Measurement: A Structural Equation Perspective, Psychological Bulletin, 110(2), pp. 305-314.

9. Bozarth, C.C. \& Edwards, S. (1997). The impact of market requirements focus and manufacturing characteristics focus on plant performance, Journal of Operations Management, 15(3), pp. 161-180.

10. Campbell, J.L. (1994). Recent trends in institutional analysis: Bringing culture back into political economy. Boston: Harvard University.

11. Chandren, S., Nadarajan, S. \& Nadarajah, G. (2012). Causes of Inventory Errors and Its impact on Supply Chain, Journal of International Academic Research, 4(5), pp. 19-22.

12. Chase, R.B. \&Aquilano, N.J. (1992). Production and Operations Management. Singapore. Irwin Inc.

13. Clark, K.B. (1994). Unionisation and Firm Performance: The Impact on Profits, Growth, and Productivity, Journal of The American Economic Review, 74(5), pp. 893-919.

14. Cleveland, G.R., Schroeder, G. \&. Anderson, J.C. (1989). A theory of production competence, Journal of Decision Sciences, 20(4), pp. 655-668.

15. Cohen, S.S. \& Zysman. J. (1988). Manufacturing innovation and American industrial competitiveness, Science, 239(1), pp. 1110-1115.

16. Cole, R.E. (1998). Learning from the quality movement: What did and didn't happen and why? California Management Review, 41(1), pp. 43-73.

17. Corbett, C. \& Van Wassenhove, L. (1993). Trade-offs? What trade-offs' competence and competitiveness, California Management Review, 35(4), pp. 107-122.

18. Crawford, K.M., Blackstone, Jr. J.H. \& Cox, J.F. (1988). A study of JIT implementation and operating problems, International Journal of Production Research, 26(9), pp. 1561-1568.

19. Crosby, P.B. (1979). Quality is free: The art of making quality certain. New York: McGraw-Hill.

20. Cua, K.O. \& Schroeder, R.G. (1999). A perceptual measure of the degree of development of proprietary equipment. Working paper. Minneapolis, University of Minnesota.

21. Danese, P., Romano, P. \& Bortolotti, T. (2012) JIT production, JIT supply and performance: investigating the moderating effects, Industrial Management \& Data Systems, 112(3), pp. 441-465.

22. Davy, J.A., White, R.E., Merritt, N.J. \& Gritzmacher, K. (1992). A derivation of the underlying constructs of justin-time management systems, Academy of Management Journal, 35(3), pp. 653-670.

23. Dean, J.W. \& Bowen, D.E. (1994). Management theory and total quality: Improving research and practice through theory development, Academy of Management Review, 19(3), pp. 392-418.

24. Eisenhardt, K.M. (1989). Building theories from case study research, Academy of Management Review, 14(4), pp. 532-550.

25. Emery, S.J., Little, R., Kwesiga, M.B., Phillips, S.D. \& Mccutcheon. R.T. (1995). Technical analysis of the employment creation potential of a National Public Works Programme, Journal of the South African Institution of Civil Engineers, 37(3), pp. 18-24.

26. Ettlie, J.E. (1988). Taking charge of manufacturing. San Francisco: Jossey-Bass.

27. Ferdows, K.J., Miller, G., Nakane, J. \&. Vollman, T.E. (1986). Evolving global manufacturing strategies: Projections into the 1990s, International Journal of Operations \& Production Management, 6(4), pp. 6-16. 
28. Finnie, W. (1997). Strategies, systems, and organizations: An interview with Russell L. Ackoff, Strategy \& Leadership. New York Publishers.

29. Flynn, B.B., Sakakibara, R.G., Schroeder, S., Bates, K.A \& Flynn, E.J. (1990). Empirical research methods in operations management, Journal of Operations Management, 9(2), pp. 250-284.

30. Flynn, B.B., Schroeder R.G. \& Sakakibara, S. (1994). A framework for quality management research and an associated measurement instrument, Journal of Operations Management, 11(4), pp. 339-366.

31. Fullerton, R.R. \& Mcwatters, C.S. (2001). Optimizing performance, Journal of Operations Management, 19 (3), Jan., pp. 81-96.

32. Fullerton, R.R. \& Mcwatters, C.S. (2002). The role of performance measures and incentive systems in relation to the degree of JIT implementation, Accounting, Organizations and Society, 27(8), pp. 711-735.

33. Fredendall, L.D., Patterson, J.W., Kennedy, W.J. \& Griffin, T. (1997). Maintenance: Modelling its strategic impact, Journal of Managerial Issues, 9(4), pp. 440-453.

34. Galbraith, J.R. (1977). Organization Design. Reading: Addison-Wesley Pub. Co.

35. Garvin, D.A. (1988). Managing quality: The Strategic and Competitive Edge. New York: Free Press.

36. Georgantzas, N.C. \& Shapiro, H.J. (1993). Viable theoretical forms of synchronous production innovation, Journal of Operations Management, 11(2), pp. 161-183.

37. Gerwin, D. (1976). A systems framework for organizational structural design, The Management of Organization Design. New York: North Holland.

38. Gomes, J.B., Menasalvas, E. \& Sousa, P.A.C. (2011). Learning recurring concepts from data streams with a context-aware ensemble, Production and Inventory Management Journal, 31(2), pp. 44-48.

39. Groenevelt, H. (1993). The just-in-time system. New York: North-Holland.

40. Hackman, J.R. \& Wageman, R. (1995). Total quality management: Empirical, conceptual, and practical issues, Journal of Administrative Science Quarterly, 40(2), pp. 309-342.

41. Hambrick, D.C. (1983). An empirical typology of mature industrial-product environments, Academy of Management Journal, 26(2), pp. 213-230.

42. Hannan, M.T. \& Freeman, J. (1984). Structural inertia and organisational change, Journal of American Sociological Review, 49(2), pp. 149-164.

43. Hayes, R.H. \& Pisano, G.P. (1994). Beyond world-class: The new manufacturing strategy, Harvard Business Review, 72(1), pp. 77-84.

44. Hayes, R.H. \& Wheelwright, S.C. (1984). Restoring our competitive edge: Competing through manufacturing. New York: Wiley.

45. Hayes, R.H. (1980). Why Japanese factories work, Harvard Business Review, 45(34), pp. 57-66.

46. Hayes, R.H., Wheelwright, S.C. \& Clark, K.B. (1988). Dynamic Manufacturing: Creating the Learning Organization. New York: Free Press.

47. Hull, J.G., Lehn D.A. \& Tedlie, J.C. (1991). A general approach to testing multifaceted personality constructs, Journal of Personality and Social Psychology, 61(6), pp. 932-945.

48. Im, J.H. \& Lee, S.M. (1989). Implementation of just-in-time systems in US manufacturing firms, International Journal of Operations \& Production Management, 9(1), pp. 5-14.

49. Imai, M. (1998). Will America's corporate theme song be "Just-in-Time"? The Journal for Quality and Participation, 21(2), pp. 26-28.

50. Inman, R.A. \& Mehra, S. (1990). The transferability of Just-in-Time concepts to American small businesses, $A$ journal of industrial Interfaces, 20(2), pp. 30-37.

51. Inman, R.A. \& Mehra, S. (1993). Financial justification of JIT implementation, International Journal of Operations \& Production Management, 13(4), pp. 32-39.

52. Khandwalla, P.N. (1974). Mass output orientation of operations technology and organizational structure, $A n$ Administrative Science Quarterly Journal, 19(1), pp. 74-97.

53. Kootanaee, A.J., Babu, K.N \& H.F. Talari. (2013). Just-in-Time Manufacturing System: From Introduction to Implement, 1(2), pp. 20-25.

54. Krajewski, L.J. \& Ritzman, L.P. (1996). Operations Management: Strategy and Analysis. Glasco: AddisonWesley Publishing Company.

55. Krajewski, J., Ritzman, P. \& Barry, E. (2009). Analysis of Operations Performance Improvement Indicators, $A$ Harvard Business Review, 62(2), pp. 143-152.

56. Lawrence, P.R. \& Lorsch, P.R. (1967). Organization and environment. Boston: Harvard University Press.

57. Lawrence, J.J. (1999). Use mathematical modeling to give your TPM implementation effort an extra boost, Journal of Quality in Maintenance Engineering, 5(1), pp. 62-69.

58. Lee, H. and Wellan, D.M. (1993). Vendor survey plan: a selection strategy for JIT/TQM suppliers, International Management \& Data Systems, 93(6), pp. 8-13.

59. Lieberman, M.B. (1990). Inventory reduction and productivity growth: A study of Japanese automobile producers. Manufacturing Strategy: The Research Agenda for the Next Decade. Boston: Kluwer Academic Publishers.

60. Macduffie, J.P. (1995). Human resource bundles and manufacturing performance: Organizational logic and flexible production systems in the world auto industry, Industrial \& Labor Relations Review, 48(2), pp. 197-221. 
61. Macduffie, J.P. \& Krafcik, J.F. (1992). Integrating technology and human resources for high-performance manufacturing: Evidence from the international auto industry.Transforming Organization. Oxford: Oxford University Press.

62. Manoj, P.K. (2011). Just in time (JIT) inventory management for enhanced operational efficiency: an 'Indianised JIT' strategy for an agro machinery manufacturing unit in Kerala, European Journal of Technology and Advanced Engineering Research, 2(1), pp. 29-39.

63. Mckone, K.E., Schroeder, R.G. \& Cua, K.O. (1999). Total productive maintenance: A contextual view, Journal of Operations Management, 17(2), pp. 123-144.

64. Mckone, K.E., Schroeder R.G. \& Cua, K.O. (1996). The impact of total productive maintenance practices on manufacturing performance, Journal of Operations Management, 16(2), pp. 333-344.

65. Mckone, K.E. \& Weiss, E.N. (1999). Total Productive Maintenance: Bridging the Gap Between Practice and Research, Production and Operations Management Journal, 7(4), pp. 335-351.

66. Mclachlin, R. (1997). Management initiatives and just-in-time manufacturing. Journal of Operations Management, 15(4), pp. 271-292.

67. Mcwatters, C.S. \& Fullerton, R.R. (2013). Firm Performance in Manufacturing Firms that use Non-financial Measures with JIT and TQM Strategies. 2013. Holland, Elsevier Science.

68. Mentzerb J.T. (2008). Financial improvement techniques, Journal of Creating consumer durable retailer customer loyalty through order fulfilment service operation, 26 (1), pp. 15-21.

69. Mehra, S. \& Inman, R.A. (1992). Determining the critical elements of just-in-time implementation, Journal of Decision Sciences, 23(1), pp. 160-174.

70. Milgrom, P. \& Roberts, J. (1995). Complementarities and fit: Strategy, structure, and organizational change in manufacturing, Journal of Accounting and Economics, 19(2-3), pp. 179-208.

71. Nadarajan, S. \& Chandren, S. (2011). Review on Causes of Raw Materials Shortages on Electronic Base Manufacturing Built to Order Perspective, European Journal of Scientific Research, 62(11), pp. 219-224.

72. Nadarajan, S., Chandren, S. \& Nadarajah, G. (2012). Innovativeness of Materials Supply to Production: A Total New Concept, A Journal of Wulfenia, 19(12), pp. 236-243.

73. Nadarajan, S., Chandren, V., Ezanee, M. \& Elias, B. (2013). Hiccups in just-in-time practices for electrical \& electronic manufacturing, Journal of International Academic Research Part B, 5(5), Sep., pp. 269-271.

74. Nakajima, S. (1988). Introduction to TPM. Cambridge: Productivity Press.

75. Noble, M.A. (1995). Manufacturing strategy: Testing the cumulative model in a multiple country context, Journal of Decision Sciences, 26(5), pp. 693-721.

76. O’brian, W.J., Formoso, T., Vrijkoef, R. \& London, K.A. (2009). Construction of supply chain management, 27(12), Dec., pp. 1265-1266.

77. O'connel, P.D.T. (1994). Engineering Management. Colorado: John Wiley and sons.

78. Ohno, T. (1988). Toyota production system: Beyond large-scale production. Cambridge: Productivity Press.

79. Olhager, J. (1993). Manufacturing flexibility and profitability, International Journal of Production Economics, 30(31), pp. 67-78.

80. Patterson, J.W., Fredendall, L.D., Kennedy, W.J. \& Mcgee, A. (1996). Adapting total productive maintenance to Asten, Inc. Production and Inventory Management Journal, 37(4), pp. 32-37.

81. Patterson, J.W., Kennedy W.J. \& Fredendall, L.D. (1995). Total productive maintenance is not for this company, Production and Inventory Management Journal, 36(2), pp. 61-64.

82. Pisuchpen, R. (2012). Integration of JIT flexible manufacturing, assembly and disassembly using a simulation approach: Assembly Automation, 32(1), pp. 51-61.

83. Porter, M.E. (1980). Competitive strategy: techniques for analyzing industries and competitors. New York: The Free Press.

84. Porter, M.E. (1990). The competitive advantage of nations. New York: The Free Press.

85. Roth, A.V., Amano, A. \& De Meyer, A. (1991). International manufacturing strategies: A comparative analysis. Managing International Manufacturing. New York: Elsevier Science Publishers.

86. Roth, A.V., Marucheck, A.S., Kemp, A. \& Trimble, D. (1994). The knowledge factory for accelerated learning practices, Journal of Planning Review, 22(3), p. 26.

87. Roth, A.V. \& Miller, J.G. (1992). Success factors in manufacturing, Business Horizons, 35(4), pp. 73-81.

88. Rouse, L.W., Toprac, M.G. \& Maccabe, N.A. (1998). The development of a statewide continuous evaluation system for the Texas Children's Mental Health Plan: A total quality management approach, The Journal of Behavioral Health Services \& Research, 25(2), pp. 194-207.

89. Sakakibara, S., Flynn, B.B. \& Schroeder, R.G. (1993). A framework and measurement instrument for just-in-time manufacturing, Journal of Production and Operations Management, 2(3), pp. 177-194.

90. Sakakibara, S., Flynn, B.B., Schroeder, R.G. \& Morris, W.T. (1997). The impact of just-in-time manufacturing and its infrastructure on manufacturing performance, Journal ofManagement Science, 43(9), pp. 1246-1257.

91. Schoenerr, J.P., Tobias, C., Power, A., Damien, N., Narasimhan, P., Ram, R. \& Samson, C. (2012). Competitive Capabilities among Manufacturing Plants in Developing, Emerging, and Industrialized Countries. Singapore: McGraww-Hill.

92. Schonberger, R.J. (1982). Japanese manufacturing techniques: Nine hidden lessons in simplicity. New York: Free Press. 
93. Schonberger, R.J. (1986). World-class manufacturing: The lessons of simplicity applied. New York: Free Press.

94. Schonberger, R.J. (1996). World class manufacturing: the next decade: Building power, strength, and value. New York: Free Press.

95. Sezen, B. (2008). Relative Effect of Design, Integration and Information Sharing on the Supply Chain Performance, An International Journal Supply Chain Management, 13(3), Feb., pp. 233-240.

96. Singh, G. and Ahuja, I.S. (2012). Just-in-time manufacturing: literature review and directions, International Journal of Business Continuity and Risk Management, 3(1), pp. 57-98.

97. Singh, S. and Garg, D. (2011). JIT system: concepts, benefits and motivation in Indian industries, International Journal of Management and Business Studies, 1(1), pp. 26-30.

98. Skinner, W. (1974). The focused factory, Harvard Business Review, 52(3), pp. 113-121.

99. Skinner, W. (1996). Three yards and a cloud of dust: Industrial management at century end, Journal of Production and Operations Management, 5(1), pp. 15-24.

100.Sriparavastu, L. \& Gupta, T. (1997). An empirical study of just-in-time and total quality management principles implementation in manufacturing firms in the USA, International Journal of Operations \& Production Management, 17(2), pp. 1215-1232.

101.Sugimori, Y., Kusunoki, K., Cho, F. \& Uchikawa, S. (1977). Toyota production system and kanban system: Materialisation of just-in-time and respect for human systems, International Journal of Production Research, 15(6), pp. 553-564.

102. Suzuki, T. (1992). New directions for TPM. Cambridge: Productivity Press.

103.Suzuki, T. (1994). Overview of TPM in process industries, TPM in Process Industries. Cambridge: Productivity Press.

104. Sriparavastu, L. and Gupta, T. (1997). An empirical study of just-in-time and total quality management principles implementation in manufacturing firms in the USA, International Journal of Operations \& Production Management, 17(2), pp. 1215-1232.

105.Swamidass, P. (2007). Matching plant flexibility and supplier flexibility: Lessons from small suppliers of U.S. manufacturing plants in India., A Journal of Operations Management, 25 (3), pp. 717-735.

106. Swamidass, P.M. (1991). Empirical Science: New Frontier in Operations Management Research, Academy of Management Review, 16(4), pp. 793-814.

107.Swamidass, P.M. \& Newell, W.T. (1987). Manufacturing strategy, environmental uncertainty and performance: A path-analytic model, Journal of Management Science, 33(4), pp. 509-524.

108. Takahashi, Y. \& Osada, T. (1990). TPM: Total productive maintenance. Tokyo: Asian Productivity Organization.

109.Tamura, T. \& E.J.O.K. (2011). Journal of International Production Research, 49(14), Jul., pp. 4299-4315.

110.Tsuchiya, S. (1992). Quality maintenance: Zero defects through equipment management. Cambridge: Productivity Press.

111.Van De Ven, A.H. \& Ferry, D.L. (1980). Measuring and assessing organizations. New York: Wiley.

112.Venkatraman, N. (1989). The concept of fit in strategy research: Toward verbal and statistical correspondence, Academy of Management Review, 14(3), pp. 423-444.

113. Venkatraman, N. (1990). Performance implications of strategic coalignment: A methodological perspective, The Journal of Management Studies, 27(1), pp. 19-41.

114.Venkatraman, N. \& Grant, J.H. (1986). Construct measurement in strategy research: A critique and proposal, Academy of Management Review, 11(3), pp. 71-87.

115.Venkatraman, N. \& Prescott, J.E. (1990). Environment-strategy coalignment: An empirical test of its performance implications, Strategic Management Journal, 11(1), pp. 1-23.

116.Vickery, S.K. (1991). A Theory of Production Competence Revisited, Decision Sciences, 22(3), pp. 635-643.

117.Vickery, S.K., Dirtige, C. \& Markland, R.E. (1993). Production competence and business strategy: do they affect business performance? Decision Sciences, 24, pp. 435-455.

118.Vuppalapati, K., Ahire, S.L. \& Gupta, T. (1995). JIT and TQM: A case of joint implementation, International Journal of Operations \& Production Management, 15(5), pp. 84-94.

119. Wacker, J.G. (1987). The complementary nature of manufacturing goals by their relationship to throughput time: A theory of internal variability of production systems, Journal of Operations Management, 7(1-2), pp. 91-106.

120.Wacker, J.G. (1996). A theoretical model of manufacturing lead times and their relationship to a manufacturing goal hierarchy, Decision Sciences, 27(3), pp. 483-517.

121.Wacker, J.G. (1998). A definition of theory: Research guidelines for different theory building research methods in operations management, Journal of Operations Management, 16(4), pp. 361-385.

122.Westphal, J.D., Gulati, R. \& Shortell, S.M. (1997). Customisation or conformity? An institutional and network perspective on the content and consequences of TQM adoption, Administrative Science Quarterly, 42(2), pp. 366-394. 